Nr 3(66), 2020, s. 211-231

https://doi.org/10.12797/Politeja.17.2020.66.15

\author{
Mirosław NATANEK (D) \\ Uniwersytet Jagielloński \\ m.natanek@uj.edu.pl
}

\title{
STAN POLSKIEJ DEMOKRACJI LOKALNEJ W ŚWIETLE STANDARDÓW RADY EUROPY I MECHANIZMU KONTROLI PRZESTRZEGANIA EUROPEJSKIEJ KONWENCJI SAMORZĄDU TERYTORIALNEGO - ASPEKTY POLITYCZNE
}

ABSTRACT The Condition of Local Democracy in Poland in Light of the Council of Europe's Standards and the European Charter of Local Self-Government Compliance Monitoring Mechanism. A Political Dimension

In the article, I will discuss a model and a mechanism of the Council of Europe member states' compliance with the European Charter of Local SelfGovernment, which was developed by the Congress of Local and Regional Authorities of the Council of Europe (CLRA). A case study analysis will be based upon investigation of three monitoring procedures launched on Poland so far. The main aim of my analysis is to examine a changing condition of local democracy in Poland as evidenced in periodical assessments carried out by CLRA's Monitoring Committee. The conclusions resulting from both audit reports and recommendations of relevant Council of Europe bodies addressed to subsequent governments of the Republic of Poland will be assessed.

Keywords: Local and Regional Democracy in Poland, European Charter of Local Self-government, Council of Europe, Congress of Local and Regional Authorities

Słowa kluczowe: demokracja lokalna i regionalna w Polsce, Europejska Karta Samorządu Terytorialnego, Rada Europy, Kongres Władz Lokalnych i Regionalnych 
$\mathrm{E}$ uropejska Karta Samorządu Terytorialnego Rady Europy (EKST RE ${ }^{1}$ ) i jej wpływ na prawo krajowe są stosunkowo dobrze opisane w specjalistycznej literaturze przedmiotu, szczególnie - co oczywiste - w naukach prawnych i administracyjnych. Główny nurt badań skupia się tu na dwóch płaszczyznach. W pierwszej kolejności pamiętać należy o ogromnym znaczeniu tej Konwencji dla Polski oraz innych państw środkowej Europy w procesie transformacji systemowej z początku lat 90. i konieczności przeprowadzenia szeregu rudymentarnych reform systemu administracyjnego i ustroju terytorialnego. Związane one były z przechodzeniem tych krajów z centralistycznego - pochodzącego z czasów tzw. realnego socjalizmu - zarządzania państwem do demokratycznego, zdecentralizowanego i związanego z dekoncentracją władzy publicznej². W nieco późniejszym okresie badacze skupiali się na kwestii wdrażania postanowień EKST w powiązaniu z coraz sprawniej działającymi już w naszym kraju samorządami wszystkich szczebli, coraz większą ich rolą w państwie i stosunkowo wysoką jakością usług publicznych przez nie świadczonych. Nie można nie wspomnieć, że w tym zakresie samorządy stały się nie tylko uzupełnieniem władzy państwowej, ale i w pewnym sensie „konkurencją” dla niej, również w aspekcie politycznym ${ }^{3}$.

Zupełnie osobną kwestią, o której należy tu wspomnieć, jest również pozytywny stosunek społeczeństwa polskiego do wszystkich tych reform, czego skutkiem jest chociażby ogromny wzrost samoidentyfikacji obywateli z ich „małymi ojczyznami” oraz gotowość do partycypacji politycznej i społecznej zwłaszcza na poziomie gminy. Kwestii tych nie można zresztą rozpatrywać w oderwaniu od członkostwa Polski w Radzie Europy oraz od całego procesu integracji Polski ze strukturami Unii Europejskiej od czasów przedakcesyjnych aż do dziśs .

Bez wchodzenia więc w szczegółową analizę prawniczą, wszystkie przytoczone tu reformy i rozważania teoretyczne na ich temat są w ostateczności wynikiem świadomej i suwerennej decyzji polskich elit politycznych z początku lat 90. o obraniu zachodnioeuropejskiego kursu w polityce zagranicznej państwa i dołączeniu do europejskich struktur gospodarczych i politycznych. Stąd w kontekście niniejszego artykułu

1 W literaturze fachowej w Polsce zamiennie używa się również nazwy Europejska Karta Samorządu Lokalnego, co wynika z tłumaczenia z języka angielskiego, lub Europejska Karta Autonomii Lokalnej, co wynika z kolei z tłumaczenia z języka francuskiego. Autor będzie jednak konsekwentnie używał nazwy jak w tytule.

2 Zob. T. Szewc, Dostosowanie prawa polskiego do zasad Europejskiej Karty Samorzadu Terytorialnego, Katowice-Bydgoszcz 2006; Local Community, Public Security, Central and Eastern European Countries under Transformation, red. J. Czapska, M. Mączyński, J. Widacki, Warszawa 2001.

3 Zob. Europejska Karta Samorzadu Lokalnego a prawo samorzadu terytorialnego, red. nauk. M. Ofiarska, Szczecin 2015; Nadzór nad samorządem a granice jego samodzielności, red. M. Stec, M. Mączyński, Warszawa 2011.

4 D. Niedźwiedzki, European Integration from the Perspective of Local Authorities. An Empirical Analysis of Six Municipalities, [w:] Local Community, Power and European Integration, red. Z. Mach, Frankfurt am Main 2017, s. 45-61; M. Natanek, Marazm czy wykorzystana szansa? Spoteczności lokalne wobec dziatań samorządów lokalnych w warunkach cztonkostwa Polski w UE i decentralizacji kraju, „Politeja” 2015, nr 33, Kraków 2015, s. 43-57. 
szczególnie podkreślić należy rolę Europejskiej Karty Samorządu Terytorialnego Rady Europy jako jedynego właściwie i fundamentalnego aktu prawnego na poziomie europejskim, na którym oprzeć się miały polskie reformy decentralizacyjne. Jest ona jednocześnie zobowiązaniem się do respektowania minimalnych praw samorządów zarówno podczas całego okresu transformacji ustrojowej, jak i przy podejmowaniu jakichkolwiek kolejnych reform w tym zakresie.

Celem niniejszego artykułu będzie przedstawianie z jednej strony wypracowanego w Radzie Europy ogólnego mechanizmu kontroli przestrzegania EKST przez te jej państwa członkowskie, które ją ratyfikowały. $Z$ drugiej, celem tekstu będzie również egzemplifikacja tego mechanizmu poprzez analizę dotychczasowych ocen stanu realizacji zobowiązań Polski wobec jej postanowień i stopnia ich respektowania przez nasz kraj. Mając na względzie ograniczenia objętościowe, Autor nie jest w stanie przedstawić wielu technicznych rozwiązań towarzyszących działalności samorządów w Polsce, a omawianych dokładnie w analizowanych dokumentach; postara się natomiast wskazać kierunek zmian i ewolucję stanu polskiej demokracji lokalnej. Interesować nas zatem będą jedynie polityczne aspekty tej ewolucji, sposób jej oceny i postrzegania przez jedyne wyspecjalizowane i powołane do tego gremium międzynarodowe, jakim jest Kongres Władz Lokalnych i Regionalnych Europy (dalej KWLR) ${ }^{5}$. Z konieczności tekst oparty zatem zostanie w dużej mierze na dostępnych materiałach organów Rady Europy odpowiedzialnych za proces monitoringu EKST, a zwłaszcza na raportach eksperckich delegatów-sprawozdawców Komitetu Monitorującego - oraz zaleceniach i rekomendacjach wydawanych przez samą KWLR i przekazywanych Komitetowi Ministrów Rady Europy.

Okoliczności powstania EKST są już opisane i zanalizowane w literaturze przedmiotu, choć warto przypomnieć, że batalia samorządów europejskich o formalnoprawne uznanie ich praw politycznych trwała na forum Rady Europy niemal trzy dekady $(1957-1985)^{6}$. Podstawową intencją uchwalenia Konwencji była postulowana przez samorządy konieczność zagwarantowania umową międzynarodową takich podstawowych praw, które zabezpieczałyby ich niezależność polityczną, administracyjną oraz finansową. Miała być jednocześnie potwierdzeniem i manifestacją rządów państw członków Rady Europy, że demokracja lokalna jest fundamentem funkcjonowania demokratycznego państwa prawa; pod tym więc względem odwoływała się bezpośrednio do realizacji Statutu Rady Europy i wartości leżących u podstaw powołania Organizacji w $1949 \mathrm{r}$.

Sama Karta, otwarta do podpisu 15 października 1985 r., podzielona została na trzy zasadnicze części, z których pierwsza definiuje główne zasady samorządu terytorialnego, druga określa minimalną liczbę artykułów, które wybiera dane państwo do uznania i wskazuje przepisy obowiązkowe dla wszystkich stron, trzecia zaś określa normy

Mimo że Kongres Władz Lokalnych i Regionalnych jest organem statutowym Rady Europy, to w oficjalnych dokumentach funkcjonuje jako Kongres Władz Lokalnych i Regionalnych Europy.

6 M. Natanek, Samorzady w Radzie Europy. Od powstania Rady Europy do szczytu wiedeńskiego 1993 roku, Kraków 2016, s. 125-140. 
i procedury ratyfikacji oraz wypowiedzenia konwencji . Najważniejszym elementem Konwencji jest oczywiście jej pierwsza część, która - prócz definicji samorządu terytorialnego - wylicza kanony i minimalne prawa samorządów w państwie demokratycznym, spośród których najważniejszymi, zdaniem Autora, są:

- uznanie zasady samorządności terytorialnej w prawie wewnętrznym, o ile to możliwe na poziomie ustawy zasadniczej lub konstytucji (art. 2);

- uznanie prawa społeczności lokalnych do elekcji poprzez pięcioprzymiotnikowe wybory ciała przedstawicielskiego, które powoływać może podległe mu organy wykonawcze (art. 3);

- uznanie zasady, że odpowiedzialność za sprawy publiczne ponosić winny organy władzy, które znajdują się możliwie jak najbliżej obywateli (art. 4);

- zasada ochrony administracyjnych granic danej jednostki samorządu terytorialnego, gdzie - możliwie w drodze referendum - skonsultować należy ze społecznością lokalną tego typu zmiany (art. 5);

- możliwość samodzielnego stanowienia przez społeczności lokalne swej wewnętrznej struktury administracyjnej (art. 6) ${ }^{8}$.

Przywołano tutaj zbiorczo najistotniejsze postanowienia Konwencji przede wszystkim dlatego, że procedura monitoringu oparta jest na badaniu stopnia realizacji zobowiązań państw w odniesieniu do każdego kolejnego jej artykułu i każdego z poszczególnych ich punktów oraz na analizie sposobów ich wypełniania przez rządy.

Jeżeli chodzi o system monitoringu przestrzegania Europejskiej Karty Samorządu Terytorialnego, to jego obecne źródła sięgają 2000 r., kiedy Komitet Ministrów Rady Europy (KM RE) przy okazji kolejnej nowelizacji Statutu Kongresu polecił regularne przygotowywanie raportów na temat sytuacji demokracji lokalnej i regionalnej oraz zapewnienia stosowania zasad EKST w odniesieniu do poszczególnych państw członkowskich RE9. Wcześniej istniejące przepisy dotyczące procedury monitoringu były co prawda opisane w dokumentach KWLR, ale nie miały one charakteru stałego mechanizmu kontroli, a poszczególne rozwiązania były rozproszone i wpisane w wiele wewnętrznych dokumentów Kongresu. Dopiero jednak 10 lat później (2010 r.) na forum KWLR pojawiły się pierwsze pomysły związane z uporządkowaniem i usprawnieniem całej procedury. Podejmując tę dyskusję, delegaci bardzo szybko zorientowali się, że skala proponowanych zmian wpłynie nie tylko na codzienne funkcjonowanie tego organu Rady, ale przede wszystkim będzie miała charakter systemowy i rzutować będzie na najistotniejsze kierunki działalności Kongresu. Stąd też zdecydowano, aby rozpocząć prace studyjne nad kompleksową reformą, co zlecono komisji ekspertów pod przewodnictwem Szweda Larsa O. Molina. Po trzech latach jego zespół przygotował obszerny raport przedstawiający szczegółowe zalecenia

Por. European Charter of Local Self-Government, Doc. CoE ETS No.122. Wejście w życie Konwencji wymagało jej ratyfikacji przez cztery państwa, dlatego weszła w życie niemal po trzech latach - 1 września 1988.

$8 \quad$ M. Natanek, Samorzady..., s. 45-47, 168-174.

9 Statutory Resolution (2000) 1 Relating to the Congress of Local and Regional Authorities of Europe, Doc. CoE CM/Res (2000) 1, zob. Art. 2, pkt. 3. 
zmian, które zawarte zostały w projektach różnych rezolucji, do przedyskutowania przez KWLR ${ }^{10}$.

Ostatecznie, podczas sesji plenarnej Kongresu w dniach 29-31 października 2013 r. uchwalone zostały trzy rezolucje, nieróżniące się jednak zasadniczo od tekstów proponowanych w raporcie Molina. Pierwsza z nich dotyczyła w głównej mierze zasad organizacji i przeprowadzania misji obserwacyjnych KWLR w państwach członkowskich podczas wyborów samorządowych na szczeblu lokalnym i regionalnym ${ }^{11}$. Druga omawiała procedury monitorowania obowiązków i zobowiązań podjętych przez państwa członkowskie Rady Europy w kontekście ratyfikacji i wypełniania przez nie zapisów Europejskiej Karty Samorządu Lokalnego ${ }^{12}$. Trzecia zaś dotyczyła kroków podejmowanych przez Kongres w okresie po wizytach monitorujących wybory samorządowe oraz rozwoju dialogu politycznego z rządami państw ${ }^{13}$. Choć w efekcie zręby obecnie obowiązującej procedury znalazły się wycinkowo w trzech różnych dokumentach KWLR rangi rezolucji, to jak widać - spośród wymienionych - najistotniejsza w kontekście niniejszych rozważań jest druga (307/2013). To w jej tekście zapisano zasadnicze uregulowania wpływające na obecny system sprawdzania zobowiązań państw członkowskich Rady Europy w kontekście podpisania i ratyfikacji przez nie EKST.

Bardzo szybko okazało się, że z pragmatycznego punktu widzenia nie jest funkcjonalne utrzymywanie stanu rozproszenia przepisów dotyczących realizacji podstawowego zadania Kongresu w różnych rezolucjach, stąd też w 2015 r. - przy okazji prac nad zmianą Regulaminu KWLR - podjęto decyzję o sformalizowaniu i opisaniu całej procedury w jednym dokumencie, a jednocześnie włączeniu tych zapisów do nowego Regulaminu Pracy Kongresu. Warto zauważyć, że podjęcie takiej decyzji dawało dwojakiego rodzaju korzyści. Po pierwsze, nareszcie wszystkie zasady związane z procedurą monitoringu przestrzegania przez państwa EKST zebrano w jednym akcie prawnym. Po drugie zaś - i to znacznie ważniejsze - regulamin pracy KWLR musi odwoływać się zawsze i być zgodny z dokumentami uchwalanymi przez nadrzędny i jedyny organ decyzyjny RE, czyli Komitet Ministrów. W ten sposób wprowadzone do Regulaminu przepisy monitorujące EKST powiązane zostały bezpośrednio z Kartą (Statutem) KWLR nadaną przez Ministrów, kiedy tworzono Kongres w 1994 r. ${ }^{14} \mathrm{~W}$ efekcie tych

10 Révision des résolutions du Congrès sur les procédures de suivi et d'observation des élections locales et regionals, Doc. CoE CLRA CG(25)13PROV.

11 Resolution on Observation of Local and Regional Elections - Strategy and Rules of the Congress, Doc. CoE CLRA/Res 306 (2010)REV.

12 Resolution on Procedure for Monitoring the Obligations and Commitments Entered into by the Council of Europe Member States in Respect of Their Ratification of the European Charter of Local Self-Government, Doc. CoE CLRA/Res. 307(2010)REV.

13 Resolution on Congress Post-monitoring and Post-observation of Elections: Developing Political Dialogue, Doc. CoE CLRA/Res 353 (2013) REV. Warto zauważyć, że dwóm pierwszym cytowanym rezolucjom pozostawiono sygnatury jeszcze z $2010 \mathrm{r}$. Nie było to możliwe w przypadku trzeciej z nich, ponieważ w pierwotnej wersji została uchwalona w marcu 2013 i z niewielkimi zmianami przyjęta ponownie w październiku $2013 \mathrm{r}$.

14 Statutory Resolution (94) 3 Relating to the Setting up of the Congress of Local and Regional Authorities of Europe, Doc. CoE CMDep/Res (94) 3. Jak już wskazano wcześniej w tekście, Statut KWLR był 
działań obecnie obowiązująca procedura monitoringu uchwalona została podczas obrad plenarnych KWLR 21 października 2016 r. jako część Rezolucji dotyczącej nowelizacji Regulaminu Kongresu i stanowi cały jego rozdział XVII ${ }^{15}$.

Zadania, które w Statucie nałożone zostały na Kongres przez Komitet Ministrów w związku z uchwalaniem EKST, znajdują swoje odbicie w strukturze KWLR. Organem odpowiadającym w całości za przeprowadzenie procedury kontroli jest więc jeden z trzech stałych komitetów utworzonych na podstawie zapisów Regulaminu - Komitet ds. Respektowania i Wypełniania Zobowiązań EKST przez Państwa Członkowskie, zwany Komitetem Monitorującym ${ }^{16}$. Warto zwrócić uwagę, że z formalnego punktu widzenia kontrola od początku dotyczyła tylko państw, które podpisały, a następnie ratyfikowały EKST. Można zatem stwierdzić, że moment ratyfikacji jest de facto pierwszym etapem całego postępowania, ponieważ państwo z tą chwilą właśnie dobrowolnie poddaje się procedurze kontroli i wyraża na nią zgodę ${ }^{17}$. Regulamin KWLR rozróżnia trzy rodzaje takiej kontroli:

- systematyczny (okresowy) monitoring, który dotyczy sprawdzenia wdrażania Karty w całości;

- monitoring szczegółowy, dotyczący wdrażania poszczególnych postanowień EKST i jej określonych artykułów;

- misje sprawdzające Kongresu, których zadaniem jest wyjaśnienie konkretnego problemu mogącego prowadzić do naruszenia zasad Konwencji.

Co ważne, opisywana dalej procedura obowiązuje w taki sam sposób, niezależnie od tego, która z wyżej wymienionych kategorii kontroli zostaje podjęta.

Przechodząc do krótkiego przedstawienia procedury kontroli Europejskiej Konwencji Samorządu Terytorialnego, trzeba na wstępie zaznaczyć, że Komitet Monitorujący pracuje w trybie ciągłym i przyjmuje półroczny plan prac, w którym wymienione są państwa wytypowane do kontroli. Jednocześnie spośród członków Komitetu jego Przewodniczący wskazuje po dwóch delegatów-sprawozdawców dla danego kraju, przy czym metody ich doboru oraz rygory związane z kontrolą są ściśle i dokładnie opisane w regulaminie ${ }^{18}$.

Podczas wizyty monitorującej sprawozdawcy spotykają się m.in. z przedstawicielami parlamentów, rządów, samorządów i organizacji je stowarzyszających czy członkami sądów konstytucyjnych i na podstawie rozmów z nimi przygotowują projekt

oczywiście wielokrotnie później nowelizowany i poprawiany; ostatnio Komitet Ministrów Rady Europy uczynił to w styczniu $2020 \mathrm{r}$.

15 Rules and Procedures of the Congress of Local and Regional Authorities of the Council of Europe, Doc. CoE CLRA/Res 409(2016).

16 Tamże, Rule 44. Oryg. Committee on the Honouring of Obligations and Commitments by Member States of the European Charter of Local Self-Government.

17 Stan obecny jest jednak taki, że wszyscy członkowie Rady Europy już to uczynili, a ostatnim państwem, które podpisało i ratyfikowało Europejską Kartę Samorządu Terytorialnego, była Republika San Marino - 23 października 2013 r. Zob. [online] https://www.coe.int/en/web/conventions/fulllist/-/conventions/treaty/122/signatures?p_auth=A5rG3sjf, 30 III 2020.

Rules and Procedures of the Congress..., Rules 81-83. 
sprawozdania. Należy zaznaczyć w tym momencie, że mają oni następnie obowiązek skonsultowania projektu przygotowanego dokumentu ze wszystkimi swoimi rozmówcami, aby ci - jeszcze na tym etapie - mieli szanse i możliwość ewentualnych komentarzy, zmian bądź uzupełnień. Po takich uzupełnieniach sprawozdawcy przedkładają swój wstępny raport Komitetowi Monitorującemu, a ten po zatwierdzeniu przekazuje go na forum KWLR do przyjęcia podczas sesji plenarnej jako rekomendację. Ostatnim sformalizowanym etapem procedury jest przesłanie przyjętej przez Kongres rekomendacji Komitetowi Ministrów, który dalej może przekazać (a de facto robi to zawsze) uchwalony w ten sposób dokument rządowi zainteresowanego państwa, jako stanowisko Rady Europy. Z punktu widzenia pragmatyki działalności Rady jako organizacji międzynarodowej istotnym jest, że uchwaloną w ten sposób przez KWLR rekomendację notyfikuje się również Zgromadzeniu Parlamentarnemu Rady Europy $\mathrm{i}$ innym jej organom, które mają obowiązek uwzględnić wnioski zawarte w dokumencie w swych wszelkich kontaktach i pracach związanych z danym państwem ${ }^{19}$. Dodać jeszcze wypada, że Regulamin przewiduje także możliwość wdrożenia - na wspólny wniosek Kongresu i władz państwa członkowskiego - procedury pokontrolnej w sprawach, które były tematem rekomendacji. Jest to zresztą element podstawowej zasady działania całej procedury monitoringu i współpracy wszystkich organów oraz agend Rady Europy z rządami państw członkowskich, jaką jest permanentny dialog politycz$n y^{20}$. Dokładny przebieg procedury kontrolnej przestrzegania i wypełniania zobowiązań zawartych w Europejskiej Karcie Samorządu Terytorialnego przedstawia poniższy schemat.

Jak wynika z powyższego, nie jest to proces skomplikowany, tym bardziej że sama Rada Europy jako organizacja demokratycznych państw ma już w swoim dorobku wcześniej wypracowane metody i procedury kontroli najważniejszych swoich Konwencji. Tak więc podobnie do innych przypadków, raport sprawozdawców, będący podstawą do uchwalenia rekomendacji przez KWLR, jest dokumentem usystematyzowanym i - jak wcześniej wspomniano - musi odnosić się do postanowień Konwencji punkt po punkcie, zgodnie z kolejnością jej artykułów ${ }^{21}$. Co należy na pewno podkreślić, to fakt, że mimo iż adresatem rekomendacji jest zawsze rząd danego państwa, to jednak jego rola i wpływ na ostateczny kształt dokumentu są porównywalne do innych konsultowanych gremiów, co ma uczynić raport bardziej wiarygodnym i obiektywnym. Wspomnieć jeszcze należy, że ogromną rolę w całym procesie odgrywa specjalnie powołana i funkcjonująca przy KWLR tzw. Grupa Niezależnych Ekspertów (GNE), którzy reprezentują obecnie 43 państwa członkowskie. Podstawową misją Grupy jest zapewnienie pomocy prawnej i merytorycznej Kongresowi w sytuacji, gdy delegaci-sprawozdawcy pełnią misję polityczną. W praktyce to właśnie na członkach

19 Tamże, Rules 84-86.

20 Tamże, Rules 80, 87.

${ }_{21}$ Zob. np. M. Natanek, Kontrola i monitoring przestrzegania Konwencji Ramowej o ochronie mniejszości narodowych Rady Europy na przyktadzie Republiki Macedonii, „Rocznik Stowarzyszenia Naukowców Polaków Litwy” 2018, t. 18, Wilno, s. 228-230. 
GNE spoczywa obowiązek przygotowania tekstu projektu rekomendacji dla Kongresu i Komitetu Ministrów ${ }^{22}$.

Procedura mechanizmu kontrolnego Europejskiej Konwencji Samorządu Terytorialnego

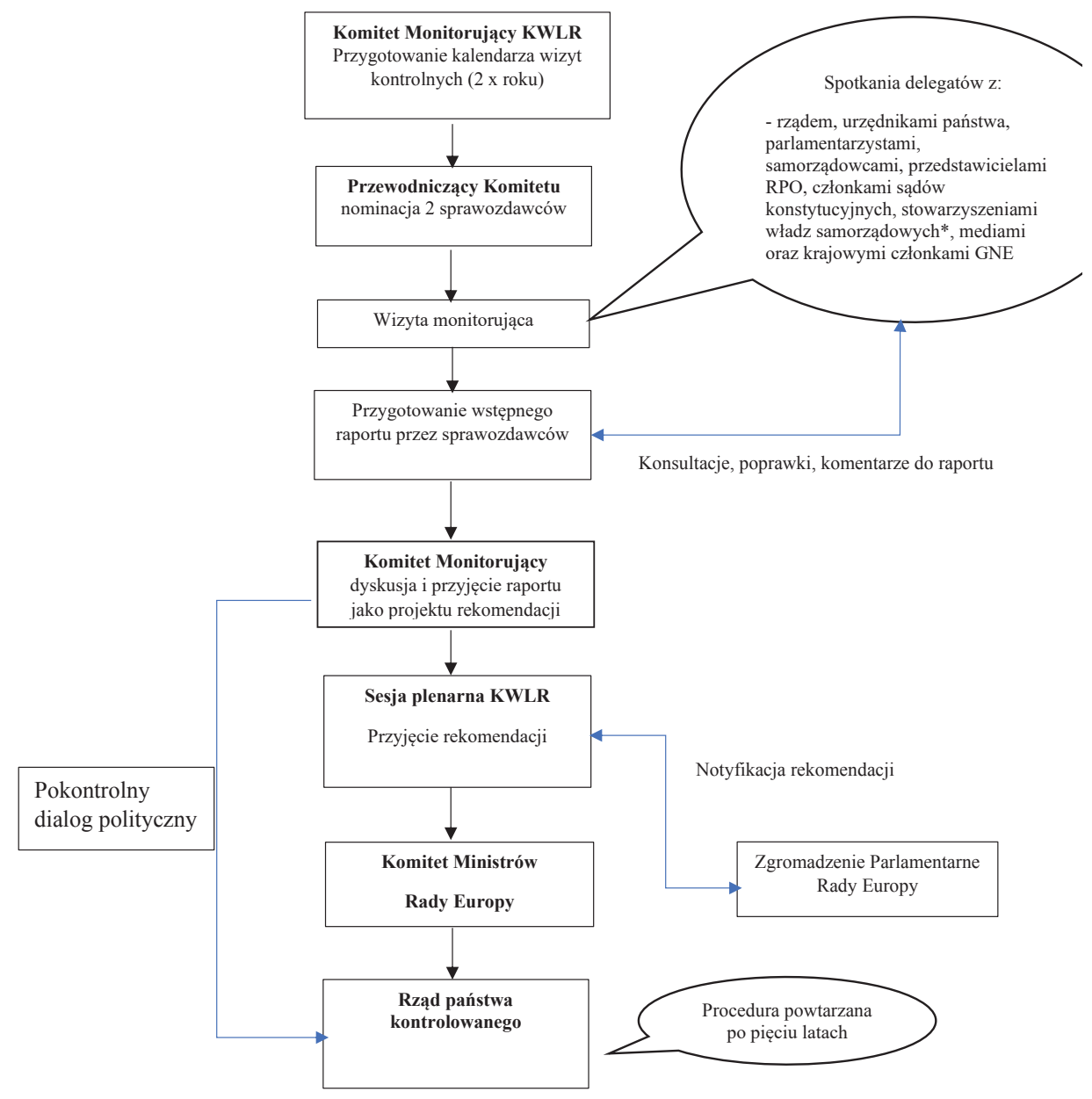

Źródło: opracowanie własne na podstawie: Resolution 307 (2010) on Procedure for Monitoring the Obligations and Commitments Entered into by the Council of Europe Member States in Respect of Their Ratification of the European Charter of Local Self-Government

22 Revised Statute of the Group of Independent Experts on the European Charter of Local Self-Government, Doc. CoE CLRA/CG/GIE(2017)01final. W praktyce Niezależna Grupa Ekspertów KWLR składa się z jednego tzw. pełnego członka, ale w większości przypadków skład grupy uzupełnia jeszcze dwóch jego zastępców - w sumie każde państwo może być w Grupie reprezentowane przez 3 osoby. Jest to zresztą reguła w organach kolegialnych Rady Europy. Wszyscy członkowie GNE są ponad to pracownikami nauki i uznanymi ekspertami nauk prawnych oraz administratywistami. 
Przechodząc do analizy raportów i rekomendacji dotyczących wykonania zobowiązań Polski w odniesieniu do Europejskiej Karty Samorządu Terytorialnego, trzeba na wstępie przypomnieć, że nasz kraj ratyfikował EKST 22 listopada 1993 r., a jej postanowienia weszły w życie na całym terytorium państwa 1 marca $1994 \mathrm{r}^{23}$ Dotychczas Polska została poddana pełnej procedurze kontroli trzykrotnie, co skutkowało oczywiście powstaniem trzech raportów i uchwaleniem odpowiednich rekomendacji przez Kongres Władz Lokalnych i Regionalnych Rady Europy. W tym kontekście warto jednakże skupić się na ocenie stanu demokracji lokalnej i regionalnej w Polsce, a przede wszystkim na wnioskach i zaleceniach, jakie zawarte zostały w poszczególnych raportach, gdyż to one pokazują w mniemaniu Autora rzeczywistą ewolucję procesu decentralizacji kraju; są także, co chyba najważniejsze, odzwierciedleniem stosunku rządów do samej idei samorządności.

Decyzja o rozpoczęciu pierwszej procedury monitoringu wobec Polski zapadła w czerwcu 2001 r., kiedy Komitet Instytucjonalny KWLR (ówcześnie nie istniał jeszcze Komitet Monitorujący) powierzył Brytyjce Kathryn Smith oraz Chorwatowi Miljenko Dorićowi funkcję delegatów-sprawozdawców ${ }^{24}$. Warto zwrócić uwagę, że ze względu na czas jej podjęcia, zarówno dla Polski, jak i dla Kongresu było to bardzo ważne wydarzenie z kilku powodów:

- po pierwsze, była to pierwsza procedura monitująca po ratyfikacji EKST;

- po drugie, miała ona ocenić zarówno stan funkcjonującej już od 10 lat demokracji lokalnej, jak i zbadać pierwsze skutki wprowadzonej w 1999 r. reformy podziału administracyjno-terytorialnego państwa i wprowadzenia trójszczeblowego systemu samorządu terytorialnego;

- po trzecie, przypadała na okres trwających już prac legislacyjnych dotyczących wprowadzenia bezpośrednich wyborów wójtów, burmistrzów i prezydentów miast;

- po czwarte wreszcie, decyzja o jej wdrożeniu została podjęta w wyniku umowy między Kongresem a Komitetem Regionów UE i prośby tego ostatniego organu o zbadanie stanu demokracji lokalnej i regionalnej w państwach kandydujących w związku ze spodziewanym w niedługim czasie zakończeniem negocjacji akcesyjnych i członkostwem tych państw w UE.

O wadze tych wszystkich uwarunkowań najlepiej też świadczą fakty, iż w składzie delegacji -co jest obecnie rzadkością - znalazło się aż trzech członków GNE, a sama wizyta monitorująca natomiast - co również jest ewenementem - przebiegała dwuetapowo

23 Zob. [online] http://prawo.sejm.gov.pl/isap.nsf/DocDetails.xsp?id=WDU19941240607, 2 IV 2020. Sformułowanie "na całym terytorium państwa” jest tu o tyle istotne, że konwencja daje prawo wyłączeń terytorialnych.

24 Autor pozwala sobie podawać nazwiska i narodowość sprawozdawców ze względu na fakt, iż - jak wspomniano w tekście - zasady ich wyłaniania są dość istotne. Jeden z nich musi reprezentować Izbę Władz Lokalnych, a drugi Izbę Władz Regionalnych KWLR. Nie mogą także reprezentować państwa kontrolowanego, państwa sąsiadującego z kontrolowanym oraz państwa, które ma z nim jakiekolwiek specjalne stosunki. Istotna jest również przynależność do różnych frakcji politycznych. Zob. Rules and Procedures..., Rule 81. 
i miała miejsce w dniach 17-15 maja w Warszawie (spotkania z przedstawicielami władz centralnych) oraz 5-7 września 2002 r. ponownie w Warszawie (spotkania z reprezentantami organizacji i stowarzyszeń władz samorządowych ${ }^{25}$ ) i Białymstoku, gdzie doszło do spotkania z samorządowcami województwa podlaskiego różnych szczebli. Ostateczny tekst raportu po konsultacjach z zainteresowanymi stronami został przekazany KWLR 30 września. Warto zauważyć, że w toku prac nad samym dokumentem polski rząd nie ustosunkował się pisemnie do poruszanych w nim kwestii i ewentualnych zarzutów, a przedstawiciele Ministerstwa Spraw Wewnętrznych i Administracji ograniczyli się jedynie do ustnych komentarzy i sprostowań ${ }^{26}$.

Generalnie stwierdzić trzeba, że raport i konkluzje w nim zawarte stawiały polskie państwo w dobrym świetle, jeśli chodzi o kierunek reform i starania władz decentralizacji kraju. Sprawozdawcy jednak, rozumiejąc, że nie jest to proces zakończony, wskazywali na szereg pułapek, niedociągnięć i rozwiązań, które mogą mieć negatywne konsekwencje dla stanu samorządności. Wśród nich na szczególną uwagę zasługują przede wszystkim rozwiązania prawne dotyczące mało klarownego i niebyt szczegółowego podziału kompetencji między administrację rządową i samorządową z jednej strony oraz między poszczególnymi poziomami samej administracji samorządowej $z$ drugiej ${ }^{27}$.

Co oczywiste, zarówno sam wydźwięk polityczny, jak i zdecydowana większość pochwał oraz krytycznych uwag, które można znaleźć w raporcie eksperckim, znalazły się w ostateczności - choć w nieco złagodzonej formie - w pierwszej pokontrolnej rekomendacji Kongresu Władz Lokalnych i Regionalnych Rady Europy. Dokument został uchwalony podczas posiedzenia Komitetu Stałego KWLR w dniu 14 listopada 2002 r. i przekazany za pośrednictwem Komitetu Ministrów polskiemu rządowi oraz organom Unii Europejskiej. Przechodząc do ocen i wniosków zawartych w rekomendacji, przede wszystkim należy je rozpatrywać z dwóch punktów widzenia. Z jednej strony zarówno sprawozdawcy w raporcie, jak i KWLR wymienili sporo uwag oraz wskazali dużą liczbę potencjalnych zagrożeń dla sprawnego funkcjonowania demokracji lokalnej. Wymienić tu należy przede wszystkim: problemy z finansami samorządów (uzależnienie od stopnia redystrybucji podatków państwowych i małe możliwości nakładania własnych podatków), kwestię niskiego stopnia profesjonalizacji samorządowej kadry urzędniczej, brak konsultacji rządu z samorządami w decyzjach bezpośrednio ich dotykających i zbyt duży stopień kontroli rządu nad nimi, niski udział i mały stopień zaangażowania się obywateli w sprawy lokalne, polityzację życia lokalnego przez ogólnokrajowe partie polityczne oraz korupcję. Mimo że były to raczej wskazania o charakterze ogólnym, to jednak dokument zwracał też uwagę na fakt, iż wszystkie wymienione kwestie mają

25 W przypadku Polski są to: Związek Miast Polskich, Stowarzyszenie Powiatów Polskich, Unia Metropolii Polskich, Związek Województw RP oraz Związek Gmin Wiejskich RP.

26 Report on Local and Regional Democracy in Poland - Explanatory Memorandum, Doc. CoE CLRA/ CG (9) 21 Part II, pkt. 1-6. Konsultowani w czasie prac nad raportem byli również prof. Michał Kulesza, prof. Jerzy Regulski oraz ówczesny Przewodniczący polskiej delegacji w KWLR - Jan Olbrycht.

27 Zob. Tamże, pkt. 74. 
bezpośredni związek i zagrażają możliwościom sprawnego pozyskiwania i absorbcji skierowanych często właśnie do samorządów funduszy europejskich ${ }^{28}$.

$\mathrm{Z}$ drugiej strony jednak podkreślić należy pozytywny wydźwięk obu omawianych dokumentów w kategoriach politycznych - na czym władzom polskim szczególnie przecież ówcześnie zależało. W rekomendacji podkreślono, że Rzeczpospolita formalnie zapewnia i gwarantuje realizację postanowień EKST, choć oczekiwane jest, aby ratyfikowała również inne ważne konwencje w tej materii. Z punktu widzenia jednak wchodzącej w europejski system prawny, polityczny i gospodarczy Polski na szczególne podkreślenie zasługują punkty mówiące, iż reformy decentralizacyjne stanowią efektywne wdrożenie zasady pomocniczości wyrażonej w Europejskiej Karcie Samorządu Terytorialnego (oraz w Traktacie z Maastricht o UE) i należy je uznać za bardzo ważne osiągnięcie w kierunku skutecznej demokracji, rozwoju gospodarczego i szybkiej integracji z Unią Europejską. Co więcej, w rekomendacji wprost znalazło się nawet stwierdzenie, że wdrażane rozwiązania Rada Europy uważa za pozytywny model dla innych krajów Europy Środkowej i Wschodniej, które chcą zreformować i zreorganizować metody funkcjonowania samorządu terytorialnego ${ }^{29}$. Trzeba więc podkreślić, że i raport, i rekomendacja z 2002 r. miały dość pozytywną wymowę i bez wątpienia wpływały korzystnie zarówno na proces integracji Polski z UE, jak i utrzymanie rządów polskich w przekonaniu o konieczności kontynuacji reform. Można więc zaryzykować twierdzenie, że mimo sporej liczby wskazanych niedociągnięć i zagrożeń kierunek zmian jest właściwy, a warunkiem powodzenia całego procesu decentralizacji państwa jest po prostu konsekwencja oraz szybka i trwała implementacja podjętych reform na poziomie lokalnym i regionalnym.

Druga procedura monitoringu wobec Polski miała miejsce w latach 2014-2015. Co powinno na początek wzbudzić pewne zdziwienie, to duży odstęp czasu między pierwszą a drugą procedurą. Analizując ten problem, należy wyrazić przekonanie, że podstawowy wpływ na tę zwłokę mógł mieć splot co najmniej kilku czynników. Po pierwsze, KWLR chciała zapewne poczekać na realne wyniki i efekty reform decentralizacyjnych podjętych przez Polskę. Po drugie, na lata 2007-2013 przypadała realizacja pierwszej pełnej perspektywy budżetowej po wejściu Polski do UE, z której lwią część funduszy pomocowych miały realizować i absorbować właśnie samorządy. Po trzecie wreszcie, zwłoka ta mogła być spowodowana opisywanymi wcześniej dyskusjami, a następnie pracami nad reformą całego procesu monitoringu wewnątrz KWLR, co musiało znaleźć odbicie w przejściowych problemach natury organizacyjnej. Rzeczywiście, analizując interwały czasowe kontroli w różnych państwach-sygnatariuszach EKST, uderza fakt ogromnego spowolnienia prac monitorujących w tamtym okresie ${ }^{30}$.

28 Recommendation 120 (2002) on Local and Regional Democracy in Poland, Doc. CoE CLRA/Rec 120(2002), s. 2-3.

29 Tamże, s. 1.

30 Np. Republika Włoska nie była kontrolowana między 1997 a 2013 r., Francja między 2000 a 2016 r., Węgry między 2002 a 2013 r. itd. Zob. [online] https://www.coe.int/en/web/congress/congress-reports\#\{,54213415“:[]\}, 16 IV 2020. Przypuszczenia co do tej ostatniej okoliczności potwierdza korespondencja Autora z sekretariatem KWLR (Pani Stéphanie Poirel), z której wynika, iż Komitet Monitorujący w tamtym czasie miał przejściowe problemy kadrowe i finansowe. 
W efekcie, w przypadku Polski do drugiej wizyty kontrolnej doszło dopiero po 12 latach od poprzedniej. Tym razem sprawozdawcami zostali Brytyjka Cynthia Hughes oraz Jos Wienen z Holandii, którzy wraz z ekspertem z GNE w dniach 20-23 maja 2014 r. spotkali się z samorządowcami z województw pomorskiego, lubelskiego i mazowieckiego oraz przedstawicielami władz miejskich Gdańska, Lublina i Opola Lubelskiego. W Warszawie odbyli natomiast rozmowy z przedstawicielami władz centralnych, sędziami Trybunału Konstytucyjnego oraz pracownikami biura Rzecznika Praw Obywatelskich i Najwyższej Izby Kontroli. Jak zwykle w takich sytuacjach, konsultowane były również organizacje zrzeszające władze samorządowe różnych szczebli.

Podobnie jak kilkanaście lat wcześniej, raport przyjęty 15 marca 2015 r. ma charakter pozytywny, zwłaszcza w jego aspektach odnoszących się do samej koncepcji systemu samorządu terytorialnego, jak i w uwagach natury politycznej. Sprawozdawcy zwracali w nim uwagę przede wszystkim na fakt, że czasie krótszym niż trzy dekady Polska osiągnęła imponujące wyniki i potrójny sukces: transformację polityczną i przejście do demokracji, transformację całego systemu gospodarczego i w końcu przejście od hipercentralizmu (sic!) do decentralizacji administracyjnej. Dokument wskazuje, że polskie ustawodawstwo i jego ramy polityczne wypełniają idee zawarte w postanowieniach EKST, a demokracja lokalna i regionalna w Polsce przedstawia z punktu widzenia postanowień Karty ogólnie akceptowalną sytuację ${ }^{31}$.

Niemniej jednak zarówno sprawozdawcy, jak i ekspert GNE zauważyli już pewne niepokojące sygnały o charakterze technicznym i na poziomie szczegółowych rozwiązań funkcjonowania samorządów, które w konkluzjach raportu wskazywali jako potencjalnie niebezpieczne dla kontynuacji tych pozytywnych zmian. Szczególnym obiektem takiej troski były oczywiście ponownie finanse samorządów - wysoce niewystarczające w ich ocenie w stosunku do przekazywanych im zadań i kompetencji, zwłaszcza na poziomie samorządów wojewódzkich. Zaniepokojenie sprawozdawców wzbudziła zwłaszcza kwestia ociągania się polskiego rządu z przedstawieniem odpowiednich rozwiązań w tym względzie, tym bardziej że w tej konkretnej sprawie zapadł nawet już wcześniej wyrok Trybunału Konstytucyjnego RP, który w sentencji z 4 marca 2014 r. wprost stwierdził, iż artykuł 31 Ustawy o dochodach jednostek samorządu terytorialnego jest niezgodny z Konstytucją RP, jak również z art. 9 ust 5. EKST, i nakazał zmienić te przepisy w ciągu 18 miesięcy ${ }^{32}$. Podobnie zresztą kwestii finansowych dotyczył zarzut o brak odpowiedniego zabezpieczenia środków na edukację, a zwłaszcza na pensje dla nauczycieli, które niewspółmiernie obciążają budżet samorządów. Jeśli chodzi o inne kwestie budzące kontrowersje, to warto może podkreślić jeszcze trzy istotne, znajdujące się w raporcie uwagi. Po pierwsze, stosunkowo słabą pozycję powiatu w systemie ustrojowym państwa oraz niejasny podział kompetencji i brak komunikacji między władzami lokalnymi a regionalnymi w zakresie planowania przestrzennego. Trzeba w końcu zaznaczyć, iż sprawozdawcy stwierdzili postępującą i zauważalną już erozję

31 Report on Local and Regional Democracy in Poland - Explanatory Memorandum, Doc. Coe CLRA/ CG/2015(28)12FINAL, s. 28-29.

32 Wyrok Trybunału Konstytucyjnego RP z dnia 4 marca 2014 r., Sygn. akt K 13/11. 
autonomii samorządów spowodowaną przeregulowaniem ich działalności przez prawo i przepisy stanowione na poziomie władz centralnych, co natychmiast odbijało się na ich pracy i efektywności. Warto zauważyć, że taką tendencję potwierdzały już zresztą wtedy badania empiryczne przeprowadzane z mieszkańcami gmin w Polsce dokładnie w omawianym czasie ${ }^{33}$. Nadmienić należy również, że rząd polski został zachęcony do podpisania i ratyfikacji uchwalonego w Utrechcie 16 listopada 2009 r. Protokołu dodatkowego do EKST o prawie obywateli do uczestnictwa w sprawach władz lokalnych $^{34}$. Zanim raport został przekazany KWLR, rząd polski złożył do niego pisemnie szereg uwag i wyjaśnień odnoszących się do najważniejszych zarzutów o charakterze finansowym, w których w głównej mierze zwracał uwagę na trwające już prace legislacyjne związane z wyrokiem Trybunału Konstytucyjnego ${ }^{35}$.

Finałem drugiej procedury kontrolnej wobec Polski była ostatecznie rekomendacja przyjęta podczas sesji plenarnej KWLR 26 marca 2015 r. Jak można było się spodziewać, zdecydowana większość zaleceń dla polskiego rządu była odzwierciedleniem wniosków zawartych w raporcie i dotyczyła usprawnienia i uregulowania systemu finansowania działalności samorządów. Co więcej, znalazły się tam wprost odwołania do poprzedniej i omawianej już wyżej rekomendacji z 2002 r., co oznaczało w praktyce, iż Kongres uważa poprzednie zalecenia za niewykonane przez kolejne rządy RP. Zalecano zatem ponownie, że pozytywnemu zjawisku, jakim jest decentralizacja uprawnień, musi towarzyszyć przekazanie odpowiednich zasobów finansowych i znalezienie nowego modelu w zakresie współfinansowania działalności samorządów, a nadmierna liczba uregulowań wpływa negatywnie na jakość usług publicznych wykonywanych przez samorządy wszystkich szczebli ${ }^{36}$.

Nie zmienia to tego, że w kategoriach politycznych stan samorządności w Polsce oceniono w 2015 r. bardzo wysoko, ze szczególnym uwzględnieniem demokracji na poziomie lokalnym oraz generalnie pozycji gminy w systemie ustrojowym państwa polskiego. Zauważona i doceniona została współpraca odpowiednich poziomów administracji w ramach Komisji Wspólnej Rządu i Samorządu Terytorialnego (dalej KWRiST), a istotny progres w tym względzie zanotowano szczególnie w sprawach dotyczących konsultowania przez rząd aktów prawnych mających wpływ na funkcjonowanie samorządów wszystkich szczebli. Rząd Polski ponownie jednak został wezwany do ratyfikacji Protokołu Dodatkowego do EKST dotyczącego prawa do uczestnictwa obywateli w sprawach władz lokalnych ${ }^{37}$.

Trzecia procedura kontrolna przestrzegania przez Polskę postanowień Europejskiej Karty Samorządu Terytorialnego rozpoczęła się wiosną 2018 r. Trzeba w tym miejscu

33 M. Natanek, Marazm czy wykorzystana szansa?..., s. 58-65.

34 Zob. Additional Protocol to the European Charter of Local Self-Government on the Right to Participate in the Affairs of a Local Authority, Doc. CETS No. 207.

35 Doc. CoEe CLRA/CG/2015(28)12FINAL.

36 Recommendation 373 (2015) on Local and Regional Democracy in Poland, Doc. CoE CLRA/Rec 372(2015), pkt 6 a-d i pkt 7 a-d.

37 Tamże, pkt 5 a-e i pkt 8. Zob. też: Additional Protocol..., Doc. CETS No. 207. 
zwrócić uwagę, porównując ją do poprzednich, że stało się to stosunkowo szybciej, niż wynikałoby z harmonogramu. Komitet Monitorujący KWLR nominował na sprawozdawców przedstawiciela Francji Mascala Mangina oraz Andorczyka Davida Baró Riba, a sama wizyta monitorująca w asyście członka GNE odbyła się w dniach 5-7 czerwca 2018 r. Tym razem sprawozdawcy spotkali się z przedstawicielami polskich samorządów w KWLR, samorządowcami województwa łódzkiego i miasta Łodzi, gminy Nowosolna, władzami Warszawy (z którymi spotkanie nie doszło do skutku podczas poprzedniej wizyty) oraz tradycyjnie z reprezentantami związków i stowarzyszeń władz samorządowych wszystkich szczebli. Warszawa była też miejscem spotkań z parlamentarzystami różnych opcji politycznych, politykami i urzędnikami administracji rządowej, NIK, RPO oraz pracownikami administracyjnymi Trybunału Konstytucyjnego ${ }^{38}$.

Trzeba podkreślić, że analiza raportu powstałego po wizycie przedstawicieli KWLR RE w 2018 r. wskazuje, iż jest on biegunowo odmienny od dwóch dotychczasowych i różni się on od poprzednich zarówno formą, jak i treścią. Jeśli chodzi o formę, to wskazać trzeba przede wszystkim niezwykłą jego szczegółowość i dokładność, włączając w to - niespotykane we wcześniejszych sytuacjach - diagramy, wykresy, tabele oraz przywoływane dane statystyczne i opracowania naukowe. Mają one w głównej mierze za zadanie zobrazowanie zawartych w dokumencie stwierdzeń, tez i wniosków. Niestety, efekty przywoływania tych danych znajdują swoje odzwierciedlenie w merytorycznej części raportu, który - należy to jasno stwierdzić - nie jest dla Polski najbardziej przychylny, zarówno biorąc pod uwagę techniczne aspekty funkcjonowania samorządów (np. podatki i finanse), jak i polityczne uwarunkowania ich działalności.

Odnosząc się bezpośrednio do konkluzji przyjętych przez Komitet Monitorujący KWLR 2 kwietnia 2019 r. w ostatecznej wersji raportu, podkreślić trzeba, że już na wstępie sprawozdawcy wspomnieli, iż do nierozwiązanych wciąż przez poprzednie rządy problemów wskazanych podczas wizyt monitorujących z 2002 i 2014 r. doszły nowe niepokojące tendencje, które muszą mieć wpływ na ostateczną ocenę stanu demokracji lokalnej, wprost nazwaną tutaj retrogresją ustroju demokratycznego. Źródło tych dość alarmujących trendów upatrywane jest w ogólnej sytuacji politycznej w państwie, u podstaw której leży konflikt między zwycięskim w wyborach 2015 r. Prawem i Sprawiedliwością a samorządowcami, pochodzącymi w większości z partii opozycyjnych. Spośród najważniejszych zarzutów wymienić tu należy następujące fakty:

- odebranie samorządom kompetencji, które wcześniej zostały już im przekazane i były przez nie w sposób zadowalający realizowane (np. w zakresie polityki ochrony środowiska);

- źle przeprowadzane konsultacje decyzji podejmowanych wobec samorządów, w tym tak istotne kwestie jak zmiany ich administracyjnych granic, np. próby powiększenia obszaru Warszawy, Opola oraz zlikwidowanie gminy Ostrowice (choć sprawozdawcy nie negowali zasadności samych decyzji, to jednak zapadały one przed zakończeniem konsultacji z mieszkańcami gmin ościennych);

38 Appendix - Programme of the Congress Monitoring Visit to Poland in 2014, Doc. CoE CLRA CG36 (2019)13final. 
- permanentne omijanie spotkań na forum Komisji Wspólnej Rządu i Samorządu Terytorialnego poprzez wprowadzanie pod obrady Sejmu projektów poselskich niewymagających takiej procedury, co z punktu widzenia autonomii samorządu w demokratycznym państwie prawa jest formulą nieakceptowalną;

- odgórne wprowadzanie sztywnych uregulowań będących dotychczas domeną samorządów (np. obniżenie pensji wójtom, burmistrzom i prezydentom miast czy też regulowanej odgórnie ceny usług publicznych świadczonych przez samorządy);

- tendencja przekazywania do realizacji samorządom coraz większych zadań bez jednoczesnego zapewnienia kompensaty finansowej, czego klasycznym przykładem była dewastująca ich finanse reforma systemu oświaty i płacone $\mathrm{z}$ funduszy samorządowych podwyżki dla nauczycieli;

- rosnąca niechęć samorządów do dochodzenia swoich praw na drodze sądowej, która jest wynikiem coraz większego braku zaufania do wymiaru sprawiedliwości w Polsce;

- brak ratyfikacji Protokołu Dodatkowego do EKST o prawie obywateli do uczestnictwa w sprawach władz lokalnych ${ }^{39}$.

Generalnie stwierdzić trzeba, że wszystkie uogólnione, a zebrane tu zaledwie w kilka punktów zarzuty były opatrzone konkretnymi przykładami i odnosiły się do zastanego stanu faktycznego i problemów zgłaszanych przez samorządy wszystkich szczebli.

Z raportu wynika, że rząd Polski podczas przygotowywania projektu tego dokumentu zareagował na niektóre uwagi w nim zawarte, dlatego też prace merytoryczne nad ostateczną redakcją tekstu trwały niemal dziesięć miesięcy. W swoich pisemnych odpowiedziach na kwestionariusz sprawozdawców Ministerstwo Spraw Wewnętrznych i Administracji (MSWiA) wskazało więc niektóre powody centralizacji kompetencji, koncentrujące się na potrzebie wdrożenia dyrektyw UE i racjonalizacji usług publicznych w celu wyrównania poziomu życia. Ten sam tok rozumowania, uzasadniający centralizację niektórych kompetencji, został zastosowany przez rząd w kwestii braku procedury konsultacji. Następnie opinia rządu negowała samo sformułowanie „centralizacja władzy", nazywając ją budowaniem jednolitych standardów dostępu do usług i świadczeń państwa opiekuńczego, które są zaledwie drobnymi korektami w stosunku do skali działań i kompetencji wspólnot lokalnych. W odniesieniu do odgórnej redukcji płac samorządowcom, Ministerstwo podkreśliło, że opinia publiczna po prostu oczekiwała obniżenia wynagrodzenia, ponieważ odczucie społeczne jest takie, iż wynagrodzenia polityków są zbyt wysokie ${ }^{40}$.

W odniesieniu do braku ratyfikacji przez Polskę Protokołu Dodatkowego do EKST Ministerstwo zwróciło w końcu słuszną uwagę, że w Polsce istnieje bardzo wiele

39 Report on Local and Regional Democracy in Poland - Explanatory Memorandum, Doc. CoE CLRA/ CG36(2019)13final.

40 Tamże, s. 25, 34. Warto przypomnieć, że przyjęte w tym względzie rozwiązanie w postaci Rozporządzenia Rady Ministrów opiera się na nowelizacji ustawy o wykonywaniu mandatu posła lub senatora, przyjętej przez Sejm w dniu 10 maja 2018 r., która przewiduje obniżkę wynagrodzeń o $20 \%$ członkom Parlamentu, co było rzeczywiście wynikiem niezadowolenia społecznego wywołanego wysokością nagród przyznanych wielu członkom rządu przez Premier Beatę Szydło. 
możliwości i odpowiednich procedur aktywizacji społeczności lokalnych, a rząd wciąż wprowadza też nowe rozwiązania w tym względzie. Co prawda wskazano tu kwestie ogromnego sukcesu budżetu partycypacyjnego, możliwość organizacji lokalnych referendów czy istnienie tzw. Młodzieżowych i Seniorskich Rad Miasta lub gminy, jednak przypomnieć należy, że wszystkie te narzędzia wdrożono już znacznie wcześniej. Rzeczywiście jednak przyznać trzeba, że wiele ciekawych i dodatkowych rozwiązań w tym względzie Parlament uchwalił w styczniu 2018 r., wprowadzając m.in. obowiązkowość realizowania budżetu obywatelskiego w miastach na prawach powiatu, jawne głosowania radnych i transmisje obrad czy np. obywatelską inicjatywę uchwałodawczą w samorządach ${ }^{41}$.

Ostatecznie Kongres Władz Lokalnych i Regionalnych Rady Europy przyjął swą rekomendację o stanie samorządności w Polsce podczas sesji plenarnej 2 kwietnia 2019 r. Mimo złagodzenia języka, jego wydźwięk właściwie w całości odpowiada raportowi Komitetu Monitorującego i w kategoriach politycznych jest dla Polski bardzo surowy w ocenie, a argumenty rządu polskiego nie przekonały samorządowców z KWLR. Dokument potwierdza więc w całości tendencje recentralizacyjne, które nasiliły się w Polsce od momentu objęcia władzy przez koalicję Zjednoczonej Prawicy, i uznaje stan erozji autonomii samorządu na każdym poziomie jego funkcjonowania. Kongres szczególnie piętnuje omijanie mechanizmu konsultacyjnego na forum KWRiST oraz wskazuje, że mimo znaczącego wzrostu ekonomicznego polskiej gospodarki zasoby finansowe, którymi władze lokalne mogą swobodnie dysponować, nie są ani adekwatne, ani współmierne do ich obowiązków i zlecanych im zadań. Za równie niepokojące uznano wzrastającą liczbę państwowych przepisów narzucających władzom lokalnym rygorystyczną procedurę ich wykonywania, ograniczającą im możliwość uwzględnienia lokalnych uwarunkowań i skuteczność administracyjną w realizacji usług publicznych. W tym duchu sformułowane zostały również zawarte w rekomendacji zalecenia, sprowadzające się do apelu do polskich władz o powrót na drogę decentralizacji i uznanie samorządów za partnera w rozwiązywaniu codziennych problemów społeczności lokalnych oraz - co ważne w kontekście dalszej ochrony demokracji lokalnej - respektowanie zaleceń Komisji Weneckiej dotyczących reform sądownictwa.

Przechodząc do wniosków, należy bez wątpienia stwierdzić, że Rada Europy wypracowała w ciągu ostatnich dwóch dekad dość przejrzysty system oceny honorowania i wypełniania przez państwa członkowskie Europejskiej Karty Samorządu Terytorialnego, a jego przesłanki powiązane zostały ze zobowiązaniem się sygnatariuszy do przestrzegania podstawowych zasad towarzyszących działalności całej organizacji zawartych w samym Statucie Rady z 1949 r. Mimo wszystko jednak Autor dopatruje się pewnych jego wad i z tego punktu widzenia można mieć pewne wątpliwości co do przejrzystości i kryteriów przyświecających samej decyzji o podjęciu procedury przeglądowej wobec konkretnych państw. Rzeczywiście, analizując ostatnie dwadzieścia lat

41 D. Sześciło, Recydywa centralizmu? Zmiany w polityce państwa wobec samorzadu po 2015 roku, Warszawa 2018, s. 24-28. Zob. też Ustawa $z$ dnia 11 stycznia 2018 r. o zmianie niektórych ustaw w celu zwiększenia udziatu obywateli w procesie wybierania, funkcjonowania i kontrolowania niektórych organów publicznych, Dz.U. 2018 poz. 130. 
działalności Komitetu Monitorującego, przyznać trzeba, że stan demokracji lokalnej sprawdzany był w wybranych z nich jedynie raz (np. Austria czy RFN), podczas kiedy inne państwa kontrolowane były aż sześciokrotnie (np. Bośnia i Hercegowina czy Mołdawia). Z jednej strony takie podejście naraża Kongres Władz Lokalnych i Regionalnych na zarzut o braku obiektywizmu, z drugiej jednak jest sprawą oczywistą, że procedura kontrolna częściej musi dotyczyć państw w toku transformacji ustrojowej bądź jest uzależniona od podejmowanych reform - tak jak to działo się w przypadku Polski, która zresztą w tym względzie plasuje się raczej wśród państw „środka stawki”. Nie wolno również zapominać, że prócz kontroli przestrzegania przepisów Konwencji, KWLR podejmuje też stały nadzór nad kolejnymi wyborami samorządowymi w państwach członkowskich, a dodatkowo - jak wskazano powyżej - utrzymuje permanentny dia$\log$ polityczny z rządami państw we wszystkich sprawach dotyczących samorządności. Biorąc więc pod uwagę, że w ramach procedury monitoringu to działacze samorządowi kontrolują rządy w asyście członków Grupy Niezależnych Ekspertów, że pozyskują oni odpowiednie informacje zarówno od urzędników państwowych, jak i od innych zainteresowanych instytucji i organów państwowych, to trudno uznać raporty i rekomendacje na ich kanwie powstałe za dokumenty stronnicze i nieobiektywne. W ocenie Autora charakteryzują się one wysokim stopniem dokładności, znajomości rzeczy, lokalnych i krajowych uwarunkowań i profesjonalizmu.

Podsumowując kwestię trzech procedur kontrolnych, które KWLR podjęła dotychczas wobec Polski, już z samego ich omówienia wynikają proste wnioski dotyczące ewolucji stanu samorządności w Polsce. Otóż w 2002 r. raport Komitetu Monitorującego i rekomendacja dla Komitetu Ministrów odnosiły się w głównej mierze do stanu samorządności związanej z uchwaloną w 1990 r. Ustawa o samorządzie gminnym. Były więc one w pewnej mierze łagodną recenzją pierwszych lat transformacji ustrojowej i wprowadzania demokracji lokalnej na najniższym szczeblu oraz próbą wskazania potencjalnych problemów związanych z podjęciem kolejnych reform decentralizujących państwo i dekoncentrujących władzę. Bez wątpienia była też ważnym składnikiem oceny przygotowania Polski do wejścia do UE i w kategoriach politycznych potwierdzeniem wypełnienia tzw. kryteriów kopenhaskich, dających też polityczną legitymację do wstąpienia do UE. Drugi raport ma znacznie bardziej techniczny charakter, odpowiadający już przyjętemu przez KWLR modelowi kontroli każdego państwa. Stąd też znajduje się w nim duża liczba bardzo szczegółowych uwag i potencjalnych zagrożeń dotyczących głównie spraw finansowego umacniania autonomii samorządów. Mimo tego w kategoriach politycznych powstała na jego kanwie rekomendacja konstatuje pełne przestrzeganie i honorowanie przez Polskę przepisów zawartych w EKST.

W kontraście do dwóch poprzednich są natomiast dokumenty z 2020 r., powstałe w wyniku trzeciej procedury monitorującej, jak również wnioski w nich zawarte. Jak wspomniano, zarówno sprawozdawcy, jak i eksperci z GNE oraz sami delegaci do KWLR uważają, że od momentu wyborów w 2015 r. nastąpił w Polsce gwałtowny powrót tendencji centralistycznych, czego efektem jest stały regres i erozja stanu demokracji lokalnej. Przyznać trzeba, że przedstawiciele polskiego rządu w dość ostrych słowach odnieśli się do tego krytycznego raportu i uchwalonej rekomendacji Rady Europy, 
twierdząc, iż przedstawiają one nieprawdę i są nieobiektywne, ponieważ sprawozdawcy spotykali się najczęściej z przedstawicielami samorządu pochodzącymi z opozycji, stąd właśnie odbicie w analizowanych dokumentach znalazł konflikt między rządem Zjednoczonej Prawicy a władzami samorządowymi ${ }^{42}$. Prawdą jest, że trzecia wizyta monitorująca odbyła się jeszcze przez wyborami samorządowymi z jesieni 2018 r., w których szczególnie PiS uzyskał bardzo dobry rezultat i przejął władzę w wielu samorządach. Niemniej, analizując dokładnie modus operandi Komitetu Monitorującego, trudno zgodzić się z tą argumentacją. Po pierwsze zauważyć należy, że regułą takich wizyt są spotkania właśnie z samorządowcami opcji przeciwnych do rządowej. Po drugie, cechą charakterystyczną polskiego systemu demokracji lokalnej jest wysokie poparcie w wyborach samorządowych dla lokalnych liderów wybieranych z własnych, lokalnych Komitetów Wyborczych. Po trzecie wreszcie - jak wskazano w tekście - konsultowane są przecież zawsze organy władzy centralnej (Sejm, Senat, rząd) oraz państwowe organy kontrolne (NIK, RPO, TK). Nawiasem mówiąc, znamiennym jest, że podczas wizyty w 2018 r. po raz pierwszy z delegacją KWLR nie spotkał się nikt z władz Trybunału Konstytucyjnego; nie zezwolono również na to żadnemu innemu sędziemu TK. W kontekście niezadowolenia rządu polskiego z ostatniego raportu koniecznym wydaje się w tym miejscu odniesienie się również do omawianych już pisemnych uwag MSWiA powstałych na etapie projektu raportu. Należy bowiem wskazać, że odpowiedzi te były nieco niespójne i wzajemnie sobie przeczące. Z jednej strony przedstawiciele rządu negowali w ogóle proces centralizacji władzy, aby przy komentarzach do innych artykułów Konwencji twierdzić, że ta centralizacja jest wynikiem wymogów wynikających z dyrektyw UE, sposobem na racjonalizację usług publicznych oraz w ostateczności po prostu wolą Parlamentu. Ten brak logiki musiał więc znaleźć odzwierciedlenie w raporcie i rekomendacji.

Co ciekawe, trzeba jasno stwierdzić, że sprawozdawcy i ekspert GNE uwypuklili bardzo satysfakcjonujący stan prawny w Polsce, jeśli chodzi o konstytucyjne i ustawowe zabezpieczenie demokracji lokalnej, stąd krytyka zawarta w raporcie odnosi się raczej do konkretnych działań administracji rządowej wpływających negatywnie zwłaszcza na ekonomiczną sytuację samorządów i ich sukcesywne osłabianie nawet bez wprowadzania zmian prawnych w tym zakresie. Regres musiał zostać również podkreślony, jeśli wziąć pod uwagę cytowane w dokumentach badania naukowe, a zwłaszcza opublikowany w 2015 r. przez szwajcarskich naukowców index LAI (Local Autonomy Index), który wtedy klasyfikował Polskę w pierwszej dziesiątce państw uznających i realizujących zasadę autonomii władz lokalnych pośród 39 badanych państw europejskich (na równi z państwami nordyckimi, RFN, Szwajcarią i nawet przed państwami zregionalizowanymi), jako państwo, które od 1990 r. uczyniło bodaj największe postępy w tym względzie ${ }^{43}$.

42 T. Żółciak, Druzgocaca opinia o naszej samorzadności. Rada Europy: Rząd centralizuje coraz więcej kompetencji, „Dziennik” z 9 IV 2019, [online] https://wiadomosci.dziennik.pl/wydarzenia/artykuly/595316,polska-lokalna-opinia-samorzadnosc-rada-europy-raport.html, 22 IV 2020

43 A. Ladner, N. Keuffer, H. Baldersheim, Local Autonomy Index for European Countries (1990-2014), Release 1.0., Brussels 2015, s. 6, 58, 68; zob. też: ciż, Measuring Local Autonomy in 39 Countries (19902014), „Regional \& Federal Studies” 2016, vol 26, nr 3, s. 321-357. 
Konkludując, Autor zgadza się z przedstawionymi w raportach Komitetu Monitorującego KWLR Rady Europy wnioskami o stanie i demokracji lokalnej w Polsce i jej ewolucji. Bez wątpienia można uznać znaczący regres pozycji ustrojowej samorządów w naszym kraju, a kierunek tych zmian uzmysławia dwie podstawowe przyczyny działań partii rządzących w tym względzie. Po pierwsze, celem takich posunięć jest osłabienie pozycji liderów lokalnych, którzy wraz z podejmowanymi wcześniej reformami stali się z czasem nie partnerem, a konkurentem politycznym. Tę kwestię wszak rozwiązano, zmieniając ordynację wyborczą do samorządów i wprowadzając pięcioletnią kadencję z możliwością jedynie jednej reelekcji. Po drugie, celem recentralizacyjnych działań rządu jest również ekonomiczne osłabianie samorząáw, które - w mniemaniu centrum zaczęly dysponować dowolnie zbyt dużymi środkami finansowymi, choć są one przede wszystkim wypadkową ogromnego wsparcia zorientowanych regionalnie funduszy europejskich, które nie są przecież już tak pewne w kolejnej perspektywie budżetowej UE. Bez względu na to, który z powyższych argumentów jest dla partii Prawo i Sprawiedliwość ważniejszy, obrazują one jednak przede wszystkim negatywne i ideologiczne podejście PiS do samej idei samorządności, a chęć centralizacji władzy jest po prostu wpisana - mylnie w przekonaniu Autora - w slogan o „silnym i sprawnym państwie”. Trudno przecież brać na poważnie pojawiające się głosy ze strony przedstawicieli rządu o groźbie federalizacji państwa, podziale na dzielnice, jego demontażu czy też uzurpowaniu sobie władzy przez samorządy ${ }^{44}$.

Na koniec tych rozważań chciałbym zwrócić uwagę na fakt, iż spraw tu opisywanych nie można rozpatrywać w oderwaniu od pozostałych działań rządu i ocen tych posunięć przez inne międzynarodowe gremia. Nie chodzi tu już nawet o nagłaśniane spory prawne toczone na forum Trybunału Sprawiedliwości UE z Komisją Europejską, ale trudno nie przypomnieć krytycznych uwag o standardach stanowionego w Polsce prawa innego organu Rady Europy, jakim jest wspominana zresztą w rekomendacjach KWLR Komisja Wenecka. W kontekście tematyki niniejszego artykułu jej opinie potwierdzają również tezę o chęci systematycznego osłabiania samorządów, jeśli uznać jej argumentację o zmianach w sądownictwie. Dość powiedzieć, że zgodnie z ostatnim raportem o stanie samorządności Rada Europy uznaje, iż na 30 badanych podczas wizyt monitorujących przepisów zawartych w Europejskiej Karcie Samorządu Terytorialnego, Polska wypełnia zobowiązania jedynie wobec $18 \mathrm{z}$ nich, 6 tylko częściowo, natomiast aż 6 uznaje się za niewypełnione ${ }^{45}$. Jest to smutna konstatacja, biorąc pod uwagę fakt, iż EKST jest ratyfikowaną przez Sejm RP umową międzynarodową i jedną z podstawowych Konwencji Rady Europy zakreślającą minimalne ramy funkcjonowania demokratycznego państwa prawa.

44 Szefernaker: większa samodzielność samorzadów to ostabienie państwa, „Puls Biznesu” z 24 VI 2019, [online] https://www.pb.pl/szefernaker-wieksza-samodzielnosc-samorzadow-to-oslabieniepanstwa-964147, 19 IV 2020.

45 Zob. Carta - Monitor of the European Charter of Local Self-Government, Poland - Monitoring Report, [online] https://www.congress-monitoring.eu/en/25-pays.html, 23 IV 2020. 


\section{BIBLIOGRAFIA}

Additional Protocol to the European Charter of Local Self-Government on the Right to Participate in the Affairs of a Local Authority, Doc. CETS No. 207.

Carta - Monitor of the European Charter of Local Self-Government, Poland - Monitoring Report, [online] https://www.congress-monitoring.eu/en/25-pays.html.

Chart of Signatures and Ratifications of Treaty 122, [online] https://www.coe.int/en/web/ conventions/full-list/-/conventions/treaty/122/signatures?p_auth=ECpzh2x9.

European Charter of Local Self-Government, Doc. CoE ETS No.122.

Europejska Karta Samorzadu Lokalnego a prawo samorzadu terytorialnego, red. nauk. M. Ofiarska, Szczecin 2015.

Europejska Karta Samorzadu Terytorialnego, sporządzona w Strasburgu dnia 15 października 1985 r., [online] http://prawo.sejm.gov.pl/isap.nsf/DocDetails.xsp?id=WDU19941240607.

Korespondencja elektroniczna Autora z sekretarzem Komitetu Monitorującego KWLR, Panią Stéphanie Poirel, w dniach 8-16 IV 2020.

Ladner A., Keuffer N., Baldersheim H., Local Autonomy Index for European Countries (1990-2014), Release 1.0., European Commission, Brussels 2015.

Ladner A., Keuffer N., Baldersheim H., Measuring Local Autonomy in 39 Countries (1990-2014), „Regional \& Federal Studies” 2016, vol. 26, nr 3, https://doi.org/10.1080/135975 66.2016.1214911.

Local Community, Public Security, Central and Eastern European Countries under Transformation, red. J. Czapska, M. Mączyński, J. Widacki, Warszawa 2001.

Nadzór nad samorzadem a granice jego samodzielności, red. M. Stec, M. Mączyński, Warszawa 2011.

Natanek M., Kontrola i monitoring przestrzegania Konwencji Ramowej o ochronie mniejszości narodowych Rady Europy na przyktadzie Republiki Macedonii, „Rocznik Stowarzyszenia Naukowców Polaków Litwy" 2018, t. 18, Wilno.

Natanek M., Marazm czy wykorzystana szansa? Spoteczności lokalne wobec dziatań samorzadów lokalnych w warunkach cztonkostwa Polski w UE i decentralizacji kraju, „Politeja” 2015, nr 33, https://doi.org/10.12797/Politeja.12.2015.33.03.

Natanek M., Samorzady w Radzie Europy. Od powstania Rady Europy do szczytu wiedeńskiego 1993 roku, Kraków 2016.

Niedźwiedzki D., European Integration from the Perspective of Local Authorities. An Empirical Analysis of Six Municipalities, [w:] Local Community, Power and European Integration, red. Z. Mach, Frankfurt am Main 2017.

Recommendation 120 (2002) on Local and Regional Democracy in Poland, Doc. CoE CLRA/ Rec 120(2002).

Recommendation 373 (2015) on Local and Regional Democracy in Poland, Doc. CoE CLRA/ $\operatorname{Rec} 372(2015)$.

Report on Local and regional democracy in Poland - Explanatory Memorandum, Doc. CoE CLRA CG36(2019)13final.

Report on Local and Regional Democracy in Poland - Explanatory Memorandum, Doc. CoE CLRA/CG (9) 21. 
Report on Local and Regional Democracy in Poland - Explanatory Memorandum, Doc. CoE CLRA/ CG/2015(28)12FINAL.

Resolution 306 (2010) on Observation of Local and Regional Elections - Strategy and Rules of the Congress, Doc. CoE CLRA 306 (2010)REV.

Resolution 307 (2010) on Procedure for Monitoring the Obligations and Commitments Entered into by the Council of Europe Member States in Respect of Their Ratification of the European Charter of Local Self-Government, Doc. CoE CLRA/Res 307(2010)REV.

Resolution 353 (2013) on Congress Post-monitoring and Post-observation of Elections: Developing Political Dialogue, Doc. CoE CLRA/Res 353 (2013) REV.

Revised Statute of the Group of Independent Experts on the European Charter of Local Self-Government, Doc. CoE CLRA/CG/GIE(2017)01 final of 17.10.2017.

Révision des résolutions du Congrès sur les procédures de suivi et d’observation des élections locales et regionals, Doc. CoE CLRA/CG(25)13PROV de 09.10.2013.

Rules and Procedures of the Congress of Local and Regional Authorities of the Council of Europe, Doc. CoE CLRA/Res 409(2016).

Statutory Resolution (2000) 1 Relating to the Congress of Local and Regional Authorities of Europe, Doc Coe. CM/Res (2000) 1.

Statutory Resolution (94) 3 Relating to the Setting up of the Congress of Local and Regional Authorities of Europe, Doc. CoE CMDep/Res (94) 3.

Szefernaker: większa samodzielność samorządów to ostabienie państwa, „Puls Biznesu” z 24 VI 2019, [online] https://www.pb.pl/szefernaker-wieksza-samodzielnosc-samorzadow-to-osla bienie-panstwa-964147.

Sześciło D., Recydywa centralizmu? Zmiany w polityce państwa wobec samorządu po 2015 roku, Warszawa 2018.

Szewc T., Dostosowanie prawa polskiego do zasad Europejskiej Karty Samorzadu Terytorialnego, Katowice-Bydgoszcz 2006.

Ustawa $z$ dnia 11 stycznia 2018 r. o zmianie niektórych ustaw $w$ celu zwięsszenia udziatu obywateli w procesie wybierania, funkcjonowania i kontrolowania niektórych organów publicznych, Dz.U. 2018 poz. 130.

Wyrok Trybunatu Konstytucyjnego z dnia 4 marca 2014 r., Sygn. akt K 13/11.

Żółciak T., Druzgocąca opinia o naszej samorządności. Rada Europy: Rząd centralizuje coraz więcej kompetencji, [online] https://wiadomosci.dziennik.pl/wydarzenia/artykuly/595316,polska-lokalna-opinia-samorzadnosc-rada-europy-raport.html.

Mirosław NATANEK - doktor, adiunkt w Instytucie Europeistyki Uniwersytetu Jagiellońskiego. Zainteresowania naukowe: działalność Rady Europy i jej samorządowy wymiar, subregionalna współpraca państw europejskich i problematyka stabilizacyjnej roli społeczności międzynarodowej w regionie Bałkanów Zachodnich. W tych dziedzinach autor monografii oraz kilkunastu rozdziałów w pracach zbiorowych i artykułów w czasopismach naukowych. 
